\title{
Viability of weed seeds in feed pellet processing
}

\author{
S. DENNIS CASH, DAVID L. ZAMORA, AND ANDREW W. LENSSEN
}

Authors are Extension Agronomist, Department of Plant, Soil and Environmental Sciences, Montana State University, Bozeman, Mont.; independent consultant, Boise, Ida.; and Research Assistant Professor, Department of Entomology, Montana State University, Bozeman, Mont., respectively. Published with the approval of the Director of the Mont. Agr. Exp. Sta.. as Journal Series J-5075.

Abstract

Federal and state agencies in several western states now require the use of noxious weed-free or noxious weed seed-free forage to hinder the spread of noxious weeds. Forage can be certified as noxious weed-free through state administered programs. Processed feeds such as pellets or cubes made from noncertified hay and uncleaned grain are some of the forage products that may be potential sources of weed infestations. This study was conducted to determine levels of weed seed contamination in alfalfa hay/grain feed pellets manufactured with commercialgrade equipment. Seeds of whitetop [Cardaria draba (L.) Hand.], spotted knapweed (Centaurea maculosa Lam.), Canada thistle [Cirsium arvense (L.) Scop.], leafy spurge (Euphorbia esula L.), and common yellow sweetclover [Melilotus officinalis (L.) Lam.] were added in known quantities to alfalfa/grass mixed hay and to barley. The hay was ground in a hammermill through a screen with $7.9-\mathrm{mm}$ diameter perforations, and the barley was ground to pass through a 2.4-mm screen. In a second experiment, uncertified 'Ladak 65' alfalfa (Medicago sativa $\mathbf{L}$.) seeds were ground with alfalfa/grass mixed hay in a hammermill and extruded through a pellet die before being ground in another hammermill with barley grain followed by extrusion through a pellet die. The Montana Department of Agriculture collected pelleted feed from various manufacturers in the state during 1993 and 1994 to estimate potential weed contamination frequency. Grinding of weed seeds with alfalfa hay or barley grain reduced emergence by 98 to $100 \%$. Grinding and pelleting reduced emergence of alfalfa seed by over $99 \%$. Weed seedlings energed from $11 \%$ of random feed pellet samples collected from Montana manufacturers. Rigorous processing such as occurs when manufacturing hay/grain pellets reduces the risk of disseminating weed seeds from pelleted feed.

Key Words: Medicago sativa, Hordeum vulgare, Cardaria draba, Centaurea maculosa, Cirsium arvense, Euphorbia esula, noxious weed seed-free forage

Financial assistance was provided by the Montana Noxious Weed Trust Fund. We also thank Denny Perry of Western States Industries, Inc., Choteau, Mont., LeRoy Johnson, Dewco, Inc., Billings, Mont, and the Montana Feed Association for their donation of equipment, labor, and technical assistance, and Dr. Jack Rumley, Prof. Emeritus, Montana State University, for his assistance in seedling identification. Lastly, we would like to express our appreciation to the USDA Forest Service, Northern Region, for their encouraging support and advice throughout this project.

Manuscript accepted 19 Apr. 1997.
Resumen

Agencias federales y estatales en varios estados del oeste requiren el uso de forraje nocivo sin maleza o sin las semillas de maleza para prevenir la extensión de maleza nociva. El forraje puede ser certificado como nocivo sin maleza a travès de programas administrativos estatales. El forraje tratado, por ejemplo, pelotillas o cubos hechos de heno no certificado o grano impuro podrían ser los productos mismos que originen la infestación de maleza. Este estudio fue llevando a cabo para determinar los niveles de contaminación de semillas de maleza en las pelotillas de grano de alfalfa y heno manufacturadas con equipo de grado comercial. Semillas de Cardaria draba (L.) Hand., Centaurea maculosa Lam., Cirsium arvense (L.) Scop., Euphorbia esula L., y Meliotus officinalis (L.) Lam. fueron añadidas en cantidades determinadas a hierba de alfalfa mezclada con heno y a la cebada. El heno fue molido con un molino (hammermill) a travès de una tela metálica de $\mathbf{2 . 4 m m}$. En un segundo experimento, semillas de alfalfa “Ladak 65" no certificadas fueron milidas con yierba de alfalfa mezclada con heno en un molino y extraídas por un mulde de pelotillas antes de ser molidas en otro milino con grano de cebada sequido por otra extración a travès de un molde de pelotillas. El Departamento de Agricultura de Montana recogió pelotillas de forraje de varios fabricantes en el estado durante 1993 y 1994 para estimar su portencia y frequencia de contaminación de maleza. El moler de las semillas de heno de alfalfa 0 el grano de cebada redujo la prominencia por 98 a $100 \%$. El moler y hacer pelotillas redujo la prominencia de semillas de alfalfa por más de $99 \%$. Plantones de maleza emergieron del $11 \%$ de una muestra de pelotillas de forraje recogidas al azar de fabricantes de Montana. El tratameinto riguroso que toma lugar al manufacturar pelotillas de grano de heno reduce el riesgo de la diseminación de semillas de maleza presentes en el forrafe de pelotillas.

The USDA Forest Service is attempting to limit the spread of nonnative plants into national forests by requiring that outfitters, recreationists, and agencies use noxious weed-seed free feed for pack and saddle stock. Western states are cooperating with the Forest Service and other agencies by establishing field inspection/certification programs to certify weed seed-free forage. Alfalfa (Medicago sativa L.) hay, grass hay, alfalfa/grass hay, cereal-grain hay, straw, and forage pellets and cubes are examples of products which can be certified as weed seed-free feeds. 
Pelleted feed is manufactured by reducing particle size through grinding and compacting the particles into pellets. The grinding process varies among feed pellet manufacturers, but most grinding is done with hammermills (Pfost 1976). Particle size is determined primarily by screen perforation diameter, but also by hammer width, the clearance between hammer tip and screen, and hammer tip speed ( 35 to $127 \mathrm{~m} \mathrm{sec}^{-2}$ ).

Pellet manufacturers typically use a tub grinder, a large capacity hammermill with a perforated screen, to grind bales weighing from 450 to $900 \mathrm{~kg}$. Grinding is completed in a smaller hammermill equipped with a screen that has hole diameters of less than $1.27 \mathrm{~cm}$ followed by pelleting and storage. Complete-ration feed pellets are processed by mixing grain and hay pellets, followed by grinding and final pelleting. Grain is ground to pass through a screen with hole diameters that are smaller than those used for hay. Hay is ground at least twice, and grain is typically ground only once before extrusion through the pellet die.

Steam is often injected into the conditioning chamber for lubrication and to liberate natural oils. Steam partially gelatinizes starches in seeds (Pfost 1976), however it is unknown if the combined effects of heat and steam pressure are sufficient to destroy viable seeds. After extrusion through the die, the pellets are bagged or conveyed to storage bins.

Few studies have examined the effects of pellet manufacturing on seed viability. Lyon and Rush (1993) found that jointed goatgrass (Aegilops cylindrica Host) survived grinding through a hammermill or roller mill. Zamora and Olivarez (1994) found that seeds of timothy (Phleum pratense L.), alfalfa (Medicago sativa L.), spotted knapweed (Centaurea maculosa Lam.), and sulfur cinquefoil (Potentilla recta L.) mixed with barley (Hordeum vulgare L.) grain can survive grinding in hammermills and extrusion through die-and-roller pellet mills. They conducted these tests with a small hammermill that may not have simulated conditions in a large commercial feed producing plant. They also did not determine the combined effects of grinding and pelleting on mortality of seeds added to hay. The objective of this study was to determine if commercial feed manufacturing equipment destroys all weed seeds. Weed seeds were introduced into alfalfa/grass mixed hay and barley grain for processing into feed pellets. Samples of pelleted feed from manufacturers throughout Montana were tested also for identification and viability of seed contaminants.

\section{Materials and Methods}

Seeds of whitetop [Cardaria draba (L.) Hand.], spotted knapweed, Canada thistle [Cirsium arvense (L.) Scop.], and leafy spurge (Euphorbia esula L.) were collected during the summer of 1994. Uncertified common yellow sweetclover [Melilotus officinalis (L.) Lam.] and 'Ladak 65' alfalfa seed were purchased locally. Percentage germination and emergence of weed seeds before grinding or pelleting were determined in concurrent laboratory and greenhouse tests. Standard germination tests were conducted by placing 100 seeds of each species on blotters in each of 4 boxes (replicates), and maintained in a controlled environment of 12 hours at $25^{\circ} \mathrm{C}$ followed by 12 hours at $15^{\circ} \mathrm{C}$. A second set of germination boxes were maintained for 7 days in the dark at $5^{\circ} \mathrm{C}$, prior to placement in the germination chamber to determine if stratification would significantly improve germination. Germinated seeds were counted daily up to 28 days.
Emergence tests in the greenhouse were conducted by planting all species in each of 4 flats (replicates) with a $10 \%$ (weight/weight) mixture of alfalfa hay meal or barley meal with Sunshine ${ }^{T M}$ media potting mix. Four additional flats without added weed seeds were included as controls. After planting, the flats were subirrigated, treated with a $0.1 \%$ (weight/volume) solution of thiophanate methyl fungicide, and covered with newspapers for 4 days. Alternating day/night temperatures in the greenhouse were 24 and $18^{\circ} \mathrm{C}$, respectively. Ambient light was extended to 16 hours with high pressure, sodium vapor lamps. Emergence counts were taken at 15-day intervals to 60 days.

The germination and emergence data were transformed (square root of the arcsine), and differences among species within a test were evaluated by the Friedman rank test (Lehman, 1975) in the Minitab Version 11 software (State College, Penn.). The Friedman test was chosen as the appropriate tool to handle nonparametric data cases. Means were separated by a multiple pairwise testing statistic at the $p=0.05$ level of significance. Across germination and emergence tests, simple analyses of variance were computed within each species on the transformed data. Actual means are presented, and mean separations at the $p=0.05$ level of significance based on the transformed data are included where appropriate.

The feed grinding and pelleting experiments were conducted at Western States Industries, Inc. in Choteau, Mont. The grinding equipment specifications are described in Table 1. The perforation diameters in the screens and pellet die sizes used in these tests are typical for those reported in a 1994 survey by the Montana Feed Association (Cash, unpublished data). New screens were installed in both the hay and grain grinding hammermills prior to the tests.

Table 1. Description of equipment used to grind alfalfa hay and barley for pelleting trials.

\begin{tabular}{|c|c|c|c|}
\hline $\begin{array}{l}\text { Equipment } \\
\text { specifications }\end{array}$ & Bale Buster ${ }^{\mathrm{TM}}$ & $\begin{array}{c}\text { Teco }^{\mathrm{TM}} \\
\text { hammermill }\end{array}$ & $\begin{array}{r}\text { JacobsonTM } \\
\text { hammermill }\end{array}$ \\
\hline Power (kW) & 56 & 149 & 56 \\
\hline Rotation (rev $\min ^{-1}$ ) & 1,750 & 1,750 & 3,600 \\
\hline Hammer speed $\left(\mathrm{m} \mathrm{s}^{-1}\right)$ & 46 & 83 & 86 \\
\hline Hammer size $(\mathrm{cm})$ & $1.3 \times 5.1 \times 25.4$ & $0.6 \times 5.7 \times 20.3$ & $0.6 \times 5.4 \times 12.1$ \\
\hline $\begin{array}{l}\text { Hammer-to-screen } \\
\text { clearance }(\mathrm{mm})\end{array}$ & no screen & 1.6 & 1.6 \\
\hline $\begin{array}{l}\text { Screen size, } 1 \times w \\
(\mathrm{~cm})\end{array}$ & no screen & $91 \times 112$ & $71 \times 56$ \\
\hline $\begin{array}{l}\text { Screen perforation } \\
\text { diameter }(\mathrm{mm})\end{array}$ & no screen & 7.9 & 2.4 \\
\hline
\end{tabular}

New screens were installed for this study.

\section{Alfalfa Hay Meal and Barley Meal}

Six $45-\mathrm{kg}$ bales of alfalfa/grass mixed hay were each inoculated with a mixture of seeds of whitetop, spotted knapweed, Canada thistle, leafy spurge, and yellow sweetclover. The seed mixture added to each bale had a known quantity of germinable seed of each species, based on availability. Each bale (replicate) passed through a Bale Buster ${ }^{\mathrm{TM}}$ (which has no screen) then through a Teco ${ }^{\mathrm{TM}}$ hammermill equipped with a $7.9-\mathrm{mm}$ screen. Each bale was ground, and the hay-weed seed meal was mechanically mixed and bagged separately for analysis. The tub grinder and the pellet 
extruder were not used in this experiment because of the large batch quantities required ( $454 \mathrm{~kg}$ minimum) for each replicate, which would have required more weed seeds than were available.

Six $11.3-\mathrm{kg}$ lots (replicates) of barley were each inoculated with a mixture of seeds of the 5 weed species listed above. The 6 grain and weed composites were then ground in a Jacobsen ${ }^{\mathrm{TM}}$ hammermill equipped with a screen perforated with $2.4-\mathrm{mm}$ diameter holes (Table 1), and bagged separately.

Greenhouse emergence tests were conducted as previously described to estimate seed survival. Six 100-g subsamples were planted for all replicate hay or barley meal samples. Emerged seedlings were counted at 15-day intervals for 45 days. Emergence data were standardized by expressing the emergence percentage of each species based on its laboratory germination. These percentage data were transformed (square root of the arcsine), and analyzed by the Friedman rank test, and means were separated at the $p=0.05$ level of significance.

\section{Feed Pellets}

In a separate test, the entire feed pellet process was evaluated. Alfalfa hay pellets were formed from a mixture of 6 bales of alfalfa/grass mixed hay plus $48.5 \mathrm{~kg}$ of 'Ladak 65' alfalfa seed. Before grinding, a hay probe was used to extract 28-g hay samples from each of the 6 bales as controls. The hay bales $(224 \mathrm{~kg}$ total) were ground through the Bale Buster ${ }^{\mathrm{TM}}$ and Teco ${ }^{\mathrm{TM}}$ hammermill equipped with a screen perforated with 7.9-mm holes. Alfalfa seeds were added directly to the Teco ${ }^{\text {TM }}$ hammermill without going through the Bale Buster ${ }^{\mathrm{TM}}$. The ground hay and seed were conveyed to the feed chamber of a pellet mill (California Pellet Mill Company, Crawfordsville, Ind.). The pellet mill was a dual speed, $112 \mathrm{~kW}$, die-and-roller pelletizer equipped with a $6.4-\mathrm{cm}$ thick die (5.1-cm effective thickness) perforated with 6.4-mm diameter holes. Steam was injected into the conditioning chamber of the pellet mill at $276 \mathrm{kPa}$. The pellets were conled and then reground with $51 \mathrm{~kg}$ of barley grain in the Jacobsen ${ }^{\mathrm{TM}}$ hammermill equipped with a screen perforated with 2.4-mm diameter holes. Reground hay pellets were thoroughly mixed with ground barley (80/20, weight/weight) and extruded through the pellet mill under the same conditions described for the alfalfa pellets.

Six samples were collected at each step in the manufacturing process: 1) unground hay prior to processing, 2) hay and seed meal after grinding in the $\mathrm{Teco}^{\mathrm{TM}}$ hammermill, 3) pelleted hay plus seed, 4) meal from reground hay pellets plus ground barley, and 5) final pellets made from the reground hay pellets plus barley. Due to the batch sizes required to utilize all steps in the pelleting process, and lack of identity control within the mill, this experiment was replicated in time. By timing the flow between the respective hammermills and the pellet extruder, it was possible to take 6 repeated samples to provide comparisons among treatments 2 through 5 above. These samples were tested for weed seedling emergence in the greenhouse using the same procedures and growing conditions as previously described.

\section{State Pellet Samples}

The Plant Industries Division of the Montana Department of Agriculture collected 70 samples of various pelletized feed manufactured in 1993 or 1994. The Montana Department of Agriculture also collected background information on the feeds and methods for making the pellets (data not reported). Unreplicated, $100 \mathrm{~g}$ samples from each pellet sample were planted in the greenhouse as previously described. Seedlings were identified and counted between 45 and 180 days after planting to survey for the potential number and types of weed seeds present in commercial pellets.

\section{Results and Discussion}

\section{Alfalfa Hay Meal and Barley Meal}

The effects of feed grinding on weed seed mortality were estimated in this experiment by greenhouse emergence tests. Hand separations and counting of seeds in hay or grain meal is very time-consuming, and may not accurately predict the viability of collected seeds. Laboratory germination in a standard 28-day test ranged from $21 \%$ for whitetop to $96 \%$ for yellow sweetclover (Table 2). Across all species, stratification by prechilling did not significantly increase laboratory germination, therefore meal and pellet samples were not stratified. Initial emergence tests were evaluated up to 60 days (data not reported), however due to very little increase from 45 days, all further trials were terminated at 45 days. Percent germination of the tested species in the laboratory was higher than percent emergence in the greenhouse in hay or barley meal. Most of this could have been due to the difference in seedling survival in the greenhouse compared to the ideal laboratory conditions. The alfalfa hay meal appeared to have a suppres-

Table 2. Seed germination in standard laboratory evaluations and greenhouse emergence of 6 species after mixing with uninfested alfalfa hay meal or barley meal.

\begin{tabular}{|c|c|c|c|c|c|c|c|c|c|c|c|c|c|}
\hline \multirow[b]{2}{*}{ Species } & \multicolumn{5}{|c|}{$\begin{array}{c}\text { Laboratory } \\
\text { germination (28-day) }\end{array}$} & \multicolumn{6}{|c|}{$\begin{array}{c}\text { Greenhouse } \\
\text { emergence (45-day) } \\
\end{array}$} & \multirow{2}{*}{\multicolumn{2}{|c|}{ Mean }} \\
\hline & \multicolumn{3}{|c|}{ No prechill } & \multicolumn{2}{|l|}{ Prechill } & $\begin{array}{r}\text { Alfalf } \\
\text { me }\end{array}$ & $\begin{array}{l}\text { hay } \\
\text { al }\end{array}$ & & \multicolumn{3}{|c|}{ Barley meal } & & \\
\hline & \multicolumn{5}{|c|}{$\ldots \ldots(\%) \cdots \ldots$} & \multicolumn{6}{|c|}{$\ldots \ldots(\%) \ldots \ldots \ldots$} & \multicolumn{2}{|c|}{$--(\%)--$} \\
\hline Yellow sweetclover & \multicolumn{2}{|c|}{$96.0 \mathrm{~A}$} & $\mathbf{a}^{1}$ & $93.5 \mathrm{~A}$ & $\mathbf{a}$ & \multicolumn{2}{|c|}{$67.5 \mathrm{~A}$} & b & \multicolumn{2}{|c|}{$81.8 \mathrm{~A}$} & $\mathbf{a b}$ & \multicolumn{2}{|c|}{$84.7 \mathrm{~A}$} \\
\hline Alfalfa & \multicolumn{2}{|c|}{$88.5 \mathrm{AB}$} & $\mathbf{a}$ & $90.8 \mathrm{~A}$ & a & \multicolumn{2}{|c|}{$73.8 \mathrm{~A}$} & a & \multicolumn{2}{|c|}{$79.8 \mathrm{~A}$} & a & \multicolumn{2}{|c|}{$83.1 \mathrm{AB}$} \\
\hline Spotted knapweed & 84.3 & B & $a b$ & $89.8 \mathrm{~A}$ & a & \multicolumn{2}{|c|}{$38.0 \mathrm{AB}$} & $\mathbf{b}$ & \multicolumn{2}{|c|}{$51.5 \mathrm{AB}$} & $\mathrm{b}$ & 65.9 & $\mathrm{BC}$ \\
\hline Canada thistle & 53.3 & BC & $\mathbf{a}$ & $60.0 \mathrm{~B}$ & a & 15.0 & $\mathrm{C}$ & $b$ & 27.5 & B & $a b$ & 38.9 & $\mathrm{CD}$ \\
\hline Leafy spurge & 25.8 & C & $a b$ & $32.5 \mathrm{~B}$ & $\mathbf{a}$ & 19.3 & $\mathrm{C}$ & b & 21,3 & B & $a b$ & 24.7 & D \\
\hline Whitetop & 21.3 & $\mathrm{C}$ & $a b$ & $35.5 \mathrm{~B}$ & $\mathbf{a}$ & 20.5 & $\mathrm{BC}$ & $\mathrm{ab}$ & 5.0 & B & $\mathrm{b}$ & 20.6 & $\mathrm{D}$ \\
\hline Mean & 61.5 & & $a b$ & 67.0 & a & 39.0 & & $b$ & 44.5 & & $\mathrm{~b}$ & & \\
\hline
\end{tabular}

${ }^{\mathrm{T}}$ Means within a column followed by the same upper case letter or within a row followed by the same lower case letter are not significantly different at $p=0.05$. 
sive effect on emergence of all species except leafy spurge and whitetop. Interestingly, whitetop had slightly higher emergence in hay meal than in barley meal. Most of these differences in greenhouse emergence were not statistically significant $(p=0.05)$, and likely were insufficient to alter our interpretation of the data. All species had adequate 45-day greenhouse emergence potentials for use as a rapid assay to measure the effects of the grinding and pelleting experiments.

In the grinding tests, 24,593 and 67,612 germinable weed seeds $\mathrm{kg}^{-1}$ were added to hay and barley, respectively (Table 3 ). Recovery of germinable weed seeds in the hay meal ranged from $0 \%$ for leafy spurge to $1.3 \%$ for whitetop. In barley meal, recovery ranged from $0 \%$ for leafy spurge to $0.3 \%$ for yellow sweetclover. Leafy spurge seed was wider but not longer or heavier than the other species (Table 4), which may have contributed to seed coat damage and its failure to emerge after being ground. Other factors that contribute to seed damage differences among species are starch and fiber content (Pfost, 1976). Seeds with higher starch contents are easier to grind (Pfost, 1976). The barley and alfalfa meals were not visually examined for intact leafy spurge seed that may have been dormant or dead because of a damaged seed coat.

Table 3. Weed seeds added to alfalfa hay or barley and subsequent greenhouse emergence in meal samples after grinding.

\begin{tabular}{lccccc}
\hline \multirow{2}{*}{ Species } & \multicolumn{2}{c}{ Germinable seed added to: } & & \multicolumn{2}{c}{ Emergence (45-day) } \\
\cline { 2 - 3 } \cline { 5 - 6 } & Alfalfa hay & Barley & & $\begin{array}{c}\text { Alfalfa meal } \\
(7.9 \mathrm{~mm})\end{array}$ & $\begin{array}{c}\text { Barley meal } \\
(2.4 \mathrm{~mm})\end{array}$ \\
\hline Spotted knapweed & $2,229^{1}$ & 3,744 & & $0.81 \mathrm{AB}^{2}$ & $0.03 \mathrm{~B}$ \\
Canada thistle & 728 & 2,187 & & $1.83 \mathrm{~A}$ & $0.19 \mathrm{AB}$ \\
Leafy spurge & 761 & 2,281 & & $0.00 \mathrm{~B}$ & $0.00 \mathrm{~B}$ \\
Whitetop & 8,265 & 24,823 & & $1.29 \mathrm{~A}$ & $0.28 \mathrm{~A}$ \\
Yellow & & & & & \\
sweetclover & 12,610 & 34,577 & & $0.93 \mathrm{AB}$ & $0.30 \mathrm{~A}$
\end{tabular}

Number of germinable seeds based on laboratory germination percentage for each species. ${ }^{2}$ Means within a column followed by the same letter are not statistically different at $\mathrm{p}=0.05$.

Fewer seedlings of whitetop, spotted knapweed, Canada thistle, and yellow sweetclover emerged after seeds were ground through a screen with 2.4-mm diameter perforations than through a screen with 7.9-mm diameter perforations (Table 3). Although direct statistical comparisons were not appropriate, the differences in mortality range from 3 to 27 times higher for the smaller screen. Zamora and Olivarez (1994) also found that quantity of seeds recovered and percent germination of recovered seeds declined as the diameter of screen perforations in a hammermill decreased. Lyon and Rush (1993) reported that fewer jointed goatgrass caryopses germinated after grinding through a screen perforated with 4-mm diameter holes compared to caryopses ground through a screen with $4.8-\mathrm{mm}$ diameter holes.

In addition to the weed seeds added in these tests, other plant species emerged from the alfalfa and barley meal. Forb species emerging from the meal were prostrate vervain (Verbena bracteata Lag. \& Rodr.), blue mustard [Chorispora tenella (Pall.)], pinnate tansymustard [Descurainia pinnata (Walt.)], catnip (Nepeta cataria L.), and creeping woodsorrel (Oxalis corniculata L.). Grass species emerging from the meal were creeping bentgrass (Agrostis stolonifera L.), cheat (Bromus secalinus L.), orchardgrass (Dactylis glomerata L.), quackgrass [Elytrigia repens (L.) Nevski], barley, red fescue (Festuca rubra L.), and
Table 4. Physical characteristics of seeds of 6 species used in pellet trials.

\begin{tabular}{lccc}
\hline \hline Test species & $\begin{array}{c}1,000-\text { Seed weight } \\
\overline{\mathrm{x}}(\mathrm{SE})\end{array}$ & $\begin{array}{c}\text { Length } \\
\overline{\mathrm{x}}(\mathrm{SE})\end{array}$ & $\begin{array}{c}\text { Width } \\
\overline{\mathrm{x}}(\mathrm{SE})\end{array}$ \\
\hline & $(\mathrm{g})$ & $(\mathrm{mm})$ & $(\mathrm{mm})$ \\
Whitetop & $0.61(0.03)$ & $2.45(0.05)$ & $1.40(0.02)$ \\
Spotted knapweed & $1.71(0.03)$ & $2.94(0.05)$ & $1.12(0.06)$ \\
Canada thistle & $0.70(0.03)$ & $2.91(0.05)$ & $0.86(0.03)$ \\
Leafy spurge & $1.79(0.03)$ & $2.40(0.05)$ & $1.54(0.03)$ \\
Alfalfa & $2.10(0.05)$ & $2.45(0.05)$ & $1.41(0.03)$ \\
Yellow sweetclover & $2.06(0.03)$ & $2.19(0.05)$ & $1.48(0.03)$ \\
$\mathrm{N}$ & 3 & 10 & 10 \\
\hline
\end{tabular}

timothy (Phleum pratense L.). These species could have been contaminants of the deliberately-added weed seeds or may have been present in the hay bales or barley.

\section{Feed Pellets}

Through the entire process, only $0.01 \%$ of the alfalfa seeds that were initially ground and pelleted with alfalfa hay were recovered in final feed pellets (Table 5). Each step in the production of feed pellets resulted in progressively fewcr seedlings emerging 45 days after planting in the greenhouse. Progressive grinding and pelleting resulted in stepwise differences in alfalfa seed mortality. Pelletizing of the hay and barley meals resulted in 92 and $86 \%$ reductions in emergence, respectively. Zamora and Olivarez (1994) also showed that the combination of grinding and extrusion through a pellet die decreased alfalfa seed viability more than either process alone. The current study showed that even after being ground and extruded through a pellet die twice, a small number of seed still survived.

Table 5. Greenhouse emergence of alfalfa seed added to hay and processed into feed pellets.

\begin{tabular}{lc}
\hline \hline Component & Emergence (45-day) \\
\hline & $\cdots(\%)--$ \\
1. Hay core & $0.00^{1}$ \\
2. Meal from mixing $224 \mathrm{~kg} \mathrm{hay}+48.5 \mathrm{~kg}$ & $4.06 \mathrm{~A}^{2}$ \\
$\quad$ alfalfa seed, hammermill $(7.9 \mathrm{~mm})$ & \\
3. Pellet from hay and seed meal & $0.50 \mathrm{~B}$ \\
4. Meal from hay pellets mixed with barley, & $0.07 \mathrm{C}$ \\
$\quad$ hammenill (2.4 mm) & $0.01 \mathrm{D}$ \\
5. Pellet from reground hay and seed plus barley &
\end{tabular}

${ }^{1}$ No alfalfa emerged; however, seedlings of cheat, blue mustard, and tansy mustard emerged at rates of 9,178 , and $464 \mathrm{~kg}-1$ hay, respectively.

${ }^{2}$ Emergence based on $88.8 \%$ laboratory germination and known quantities of ingredients added.

A higher percentage (4.06\%) of alfalfa seeds emerged after a single grinding (Table 5) than from the average of all weed species $(0.97 \%)$ (Table 3). Both were ground through the Teco ${ }^{\mathrm{TM}}$ hammermill with the same size screen. Seed coats of alfalfa may be harder than the seed coats of the other species allowing more seed to survive grinding. However, alfalfa seed did not go through the Bale Buster ${ }^{\mathrm{TM}}$, which also may have destroyed some seed. Three weed species (cheat, blue mustard, and tansy mustard) emerged from the core samples of the hay bales prior to grinding and pelleting.

Temperature of the pellets immediately after extrusion was approximately $56.7^{\circ} \mathrm{C}$, and the pellets were exposed to this temperature briefly. Zamora and Olivarez (1994) measured pellet die temperatures of 57.2 and $62.2^{\circ} \mathrm{C}$ for hay-grain and grain pellets, 
respectively. After extrusion, pellets are quickly cooled to about $8^{\circ} \mathrm{C}$ above ambient temperature (Robinson 1976). Exposure to $56.7^{\circ} \mathrm{C}$ probably has little affect on alfalfa seed viability. In other studies, viability of unimbibed seeds of 8 weed species tested was unaffected after 6 hours exposure to $70^{\circ} \mathrm{C}$ (Egley 1990). Standard methods used by the Animal and Plant Health Inspection Service for complete sterilization (seed death) require autoclaving for 15 min at 69 kilopascal with an approximate temperature of $115^{\circ} \mathrm{C}$ or injecting steam into loose material until all parts reach $100^{\circ} \mathrm{C}$ (personal communication, Klag). The Animal and Plant Health Inspection Service also found that exposing various federal noxious weed seeds to $100^{\circ} \mathrm{C}$ for $15 \mathrm{~min}$ does not kill all secds (unpublished data, Westbrooks, Whiteville, N.C.).

\section{State Pellet Samples}

Eleven percent of the pellet samples collected from Montana feed manufacturers had 1 or more weed seedlings emerge (data not reported). Six samples had a white clover (Trifolium repens L.) seedling, 1 had a wild mustard [Brassica kaber (D.C.) Wheeler] seedling, and 1 sample had 6 plants from 4 species wild mustard, common lambsquarters (Chenopodium album L.), catnip, and prostrate vervain. Contaminated samples had weed seed densities ranging from 10 to $60 \mathrm{~kg}^{-1}$ pellets. Most of the samples with the lowest level of contamination were finished products. The sample with 60 seeds $\mathrm{kg}^{-1}$ of pellets was intended for further grinding and pelleting with hay. Only 21 of the 70 samples tested were manufactured specifically for use as horse feed. Weeds emerged from only 2 of these 21 samples, with each having 1 white clover seedling. White clover was also 1 of 2 species (4 seedlings total) that emerged during a similar test of 80 pellet samples conducted in Montana in 1991 (unpublished data, Fay). It is unknown if the white clover came from the pellets or from the greenhouse potting soil where it can be a common contaminant.

The background information collected with the state pellet samples was insufficient to make any correlations between weed seed occurrence and pellet components or manufacturing processes. Details of the manufacturing procedure for specific batches of pellets may be nonexistent because of the variable conditions required to pellet feed. The American Feed Manufacturer's Association has said that every run should be approached from the viewpoint of a new formulation (MacBain 1967).

Grain and alfalfa hay often contain weed seeds that are incorporated into feed pellets. The number of weed seeds in grain or alfalfa hay must be known to predict if the pellets will contain viable seeds. Zamora and Olivarez (1994) concluded that because most grain lots used for feed pellets are not cleaned it is highly probable that feed pellets manufactured from it would be contaminated. In a drillbox survey, $85 \%$ of all the samples of uncleaned grain (spring wheat, winter wheat, and spring barley) contained weed seeds (Dewey et al. 1985). In that study, the average number of weed seeds in uncleaned grain was about 550 seeds $\mathrm{kg}^{-1}$.

Most weed seeds in uncleaned grain will be destroyed during the pelleting process. Average weed emergence in grain was $0.16 \%$ after grinding to pass through a screen with hole diameters of $2.4 \mathrm{~mm}$ (Table 3 ). If percent emergence is reduced by another 84 to $92 \%$ after extrusion through a pellet die as occurred for alfalfa seeds (Table 5 ), $0.02 \%$ of all weed seeds in grain would still be viable. There would be only 0.02 viable weed seeds $\mathrm{kg}^{-1}$ of horse feed pellets consisting of $20 \%$ grain by weight if $0.02 \%$ survived pelleting.

\section{Conclusions}

Seeds in unprocessed hay consumed by livestock before entering national forests may likely spread more exotic species than seed in feed pellets. The pellet manufacturing system tested in this study destroyed over $99 \%$ of viable weed seeds added to alfalfa hay or grain. Based on this study and previous work, it appears that most seed mortality is caused in feed grinding to pass through progressively smaller perforations. Heat and steam pressure at the pellet extruder reduced alfalfa seed survival by over $86 \%$. Our results document that pellet processing can greatly reduce the germination of weed seeds. Livestock can excrete viable seeds of many species consumed in contaminated feed for several days after consumption (Janzen 1981, Thill et al. 1986). The introduction of weed seeds into national forests consumed by livestock before entering national forests is likely impossible to stop. There is a very low probability that weed seeds will survive grinding and pelleting followed by mastication and digestion. It appears that feed pellets formulated from noncertified alfalfa hay or grain pose only a slight risk of contaminating public lands, as long as these products are manufactured with similar processes and ground through similar sized screens as were used in this study. To fully understand the potential of feed to spread weed seeds to national forests, data are needed on the speices and amount of weed seed in certified, weed-free forage, noncertified forage, and cubed hay.

\section{Literature Cited}

Dewey, S.A., D.C. Thill, and P.W. Foote. 1985. Weed seed contamination of cereal grain seedlots-a drillbox survey. CIS No. 767, Univ. of Idaho, Ext. Servi., Agr. Exp. Sta.

Egley, G.H. 1990. High-temperature effects on germination and survival of weed seeds in soil. Weed Sci. 38:429-435.

Janzen, D.H. 1981. Enterolobium cyclocarpum seed passage rate and survival in horses, Costa Rican pleistocene seed dispersal agents. Ecol. 62:593-601.

Lehman, E.L. 1975. Nonparametrics: Statistical methods based on ranks. Holden-Day, Oakland, Calif.

Lyon, D.J. and I.G. Rush. 1993. Processing reduces seed germination and emergence of jointed goatgrass. J. Prod. Agr. 6:395-398.

MacBain, R. 1967. Pelleting: formulation, conditioning, operating techniques. P. 1-24 In: Pelleting Animal Feed. American Feed Manufacturer's Association, Chicago, Ill.

Pfost, H.B. 1976. Grinding and rolling. P. 71-84, In: H.B. Pfost (ed.), Feed manufacturing technology. Feed Production Council, American Feed Manufacturing Association, Inc., Chicago, Ill.

Robinson, R.A. 1976. Pelleting -introduction and general definitions. P. 96-103. In: H.B. Pfost (ed.), Feed manufacturing technology. Feed Production Council, American Feed Manufacturing Association, Inc., Chicago, Ill.

Thill, D.C., D.L. Zamora, and D.L. Kambitsch. 1986. The germination and viability of excreted common crupina (Crupina vulgaris) achenes. Weed Sci. 34:237-240.

Zamora, D.L. and J.P. Olivarez. 1994. The viability of seeds in feed pellets. Weed Tech. 8:148-153. 